\title{
Patho-physiological investigation of anorexia of cattle at Sylhet district in Bangladesh
}

\author{
Rahman $\mathrm{MM}^{1}$, Rahman $\mathrm{MM}^{2 *}$, Sharmin $\mathrm{KN}^{3}$, Hossain $\mathrm{MM}^{2}$, Rashid $\mathrm{MH}^{4}$ and Ahmed $\mathrm{S}^{5}$ \\ ${ }^{1}$ TE, ACI Godrej Agrovet Privet Ltd, ${ }^{2}$ Department of Medicine, ${ }^{3}$ Department of Microbiology and Immunology, \\ ${ }^{5}$ Department of Animal Nutrition, Sylhet Agricultural University, Sylhet, Bangladesh, ${ }^{4}$ Department of \\ Microbiology and Virology, Jhenidah Government Veterinary College, Bangladesh.
}

[Received: December 07, 2015; Accepted: December 21, 2015]

\begin{abstract}
The present study was designed to explore the patho-physiological investigation of anorexia of cattle at Sylhet district, Bangladesh. The aim of this study has been conducted to determine the patho-physiological causes of anorexia in cattle during the study period started from September to December in Bishwanath upazila veterinary hospital, Sylhet. Anorexia is one of the most common illness among female cattle in Bangladesh. In this study, a total number of 155 diseased cattle, 100 cattle were found having anorexia due to parasitic, infectious, nutritional deficiency and unknown etiology. Results of this study showed most anorexia developed due to parasitic infestation $(41 \%)$ which was determined by feces examination and observing the body condition of the animal. The female cattle developed anorexia in higher rate $(67 \%)$. The early age (less than 1year) of the cattle were found mostly to develop anorexia in cattle, may be due to parasitic and nutritional deficiencies cause.
\end{abstract}

Key words: Anorexia, cattle, parasitic, infectious, nutritional, deficiency.

\section{INTRODUCTION}

Bangladesh is an agro-based country. Livestock is one of the important parts of agriculture. Nevertheless, cattle population is one of the major parts of livestock. Cattle population of Bangladesh is 23.40 million ${ }^{[10]}$. Cattle are a part of the property, possession and profession of rural farmers. Not only that, they are an easily 'convertible currency' and a reliable 'living bank' to serve the immediate needs of the rural masses in several communities. The overall food production from crops is declining. However, there has been an immense increase in the human population. Increased food production through simple low-cost and environment-friendly farming techniques is warranted of all domestic animals ${ }^{[9]}$. Asian Cattle holds the greatest promise and potential for production. In Bangladesh, Cattle play an important role in domestic economy and trade. This species is useful in terms of draft power, high ecological potential on productivity and biological performances ${ }^{[14]}$. On the contrary, the Cattle of Bangladesh have been recognized to possess low reproductive performance ${ }^{[3]}$. In our country cattle are mostly suffer in bacterial, viral, parasitic and nutritional diseases. All diseases most common symptoms is anorexia.This review examine the occurrence, physiological effects, and possible causes of voluntary reduction of food consumption in parasitic infection infections with protozoa and helminthes. Parasitologists use the term anorexia or inappetence in place of the longer expression. Either is acceptable, as the common definition of both is loss or lack of appetite. Because the word anorexia is more frequently used and because there is a subjective connotation to the word appetence and I can not know whether this is experienced by animals other than man. I have used anorexia throughout this review. Anorexia is taken to refer to any reduction in food consumption, wheather slight or complete. Anorexia is a lack or loss of appetite ${ }^{[7]}$. Anorexia which is also caused by many of the same factors that causes anorexia. The syndrome occurs in the majority of patients with advanced, refractory malignancies. The signs and symptoms of the anorexia syndrome include loss of lean tissue, a decline in performance status, fluctuations in resting energy expenditure, and loss of appetite ${ }^{[18]}$. Anorexia including emotional disorders, infections, pain, obstruction, constipation, and other symptoms which independently can reduce appetite, weight and strength. Two aspects of anorexia deserve special comment. First, body composition assessment shows that these patients lose a disproportionate and excessive amount of lean tissue. Although weightlosing patients lose both fat and lean tissue, it is the loss of lean tissue, particularly skeletal muscle, which is most profound. Second, aggressive feeding does not reverse the anorexia weight loss syndrome. For example, multiple studies that examined the role of total parenteral nutrition in patients found no clinical benefits ${ }^{[8]}$. Evidently the anorexia weight loss syndrome is a result of the effects of cancer more than the absence of sufficient nutrition. In Bangladesh, there are no more study has been found belonging to anorexia. In view of above considerations, the present study is proposed with the objectives to study on patho-physiological investigation of anorexia of cattle at Sylhet district. 


\section{MATERIALS AND METHODS}

\section{Study area}

The data were collected from Upazila Veterinary Hospital; Bishwanath, Sylhet. Biswanath is located at $24.8083^{\circ} \mathrm{N} 91.7639^{\circ} \mathrm{E}$. It has 26,346 households and a total area of $214.5 \mathrm{~km}^{2}$. Biswanath borders Jagannathpur, Balagonj and Sylhet Town. It is located between Sylhet City and Jagannathpur Tana. The climate of this area is humid subtropical with a predominantly hot and humid in summer and a relatively cold winter. Annual maximum temperature is $33.2^{\circ} \mathrm{C}$ and minimum is $13.6^{\circ} \mathrm{C}$; annual rainfall $3334 \mathrm{~mm}^{[5]}$.

\section{Period of collection data}

The necessary data were collected from Upazila Veterinary Hospital, Bishwanath, Sylhet, during the period from September to Desember 2012.

\section{Data collection procedure}

The data was collected from the daily patient registrar book of UVH, Bishwanath and based on the clinical sign and follow up treatment of the diseased cattle. All data were easily recorded with the help of pre-form questionnaire. To attain the objective registered cattle were grouped according to the age, sex and cause of anorexia. Sex of the cattle were divided into 2 groups; Male and Female cattle. Cattle were categorized into 3 age groups that were $0-1$ year, 1-3 years and above 3 years of age. The causes of anorexia were categorized into parasitic, nutritional, infectious and unknown group. respiratory tract was detected through stethoscope. The preputial mucosa and glans penis were examined for the presence of any purulent discharge or ulceration.

\section{Diseases diagnosis}

The viral, bacterial, protozoal, fungal and mixed infections were diagnosed by owner's complaint \& specific clinical signs of the diseases $[11,12]$. The symptomatic signs used to presumptive diagnosis were made. The long-term and short-term history of the herd and patient should be considered.

\section{Analytical techniques}

The obtained data were analyzed by using computerized Microsoft Excel-2007 program and analyze the all data.

\section{RESULTS}

To determine the Physiological and pathological causes of anorexia of Cattle, the data recorded based on age, sex and causes of anorexia. The causes of anorexia have been determined by sign, symptoms and follow up result after treatment. During study period, total 155 cattle were observed where 100 cattle showed anorexia symptoms due to parasitic, infectious, nutritional deficiency and unknown causes.

In this study, total observed 155 cattle during study period where 100 cattle are developed to anorexia. The anorexia occurs due to parasitic, infectious,

Table 1 . The number and percentage of anorectic cattle due to different causes

\begin{tabular}{cccccccc}
\hline \multirow{2}{*}{ Causes } & \multicolumn{2}{c}{$\begin{array}{c}\text { Age } \\
(0-1 \text { year })\end{array}$} & \multicolumn{2}{c}{$\begin{array}{c}\text { Age } \\
(1-3 y e a r s)\end{array}$} & \multicolumn{2}{c}{$\begin{array}{c}\text { Age } \\
\text { (above 3 years) }\end{array}$} & \multirow{2}{*}{ Percent $(\%)$} \\
\cline { 2 - 7 } & Male & Female & Male & Female & Male & Female & \\
\hline Parasitic & 6 & 9 & 3 & 8 & 5 & 10 & 41 \\
Nutritional & 4 & 9 & 2 & 6 & 0 & 1 & 22 \\
infectious & 7 & 7 & 8 & 12 & 0 & 0 & 34 \\
Unknown & 1 & 0 & 1 & 1 & 0 & 0 & 3 \\
Total & 18 & 25 & 14 & 27 & 5 & 11 & - \\
Percent $(\%)$ & $18 \%$ & $25 \%$ & $14 \%$ & $27 \%$ & $5 \%$ & $11 \%$ & 100 \\
\hline Age $(\%)$ & \multicolumn{7}{c}{$41 \%$} \\
\hline
\end{tabular}

\section{Physical Examination}

Information of affected animals were recorded according to age and sex recorded by carefully asking questions to the owner or farmers ${ }^{[4]}$ Body condition score, temperature, consistency of feces and any prominent clinical signs were also recorded. The body surface of calves and adult was examined for any swelling, wound or hernia ring or any outgrowth. The hindquarter and thigh muscles were observed to see lameness crepitation on palpation. The animals were palpated to detect any enlargement, reddening of udder or pain. In animals, mouth and feet were observed to detect any vesicle wound or salivation. Different joints of the animals were observed through palpation and were examined to detect any swelling or pain. Abnormal sound of nutritional deficiency and unknown causes which determined by clinical sign of the diseases, feces examination of cattle and response to treatment. Here showed that anorexia developed due to parasitic infestation (41\%), nutritional deficiency (22\%), infectious (34\%) and unknown 3\% (Table 1). The male and female of 0-1 year, 1-3 year and above 3 years age group were recorded $18 \%$ and $25 \% ; 14$ and $27 \%$; $5 \%$ and $11 \%$ respectively. The percentage of anorexia developed in different age group varies that was $0-1$ year, 1-3 year and above 3 years $43 \%, 41 \%$ and $16 \%$ respectively.

\section{DISCUSSION}


The results of this study revealed that the female of every age group were mostly developed anorexia. The parasitic diseases were severely infested the female cattle. The similar findings were reported by several researchers [16, 17]. Anorexia causes both productive and reproductive performance. Serious annual economic losses have been estimated due to various parasitic diseases at Savar military farm Dhaka ${ }^{[1]}$. Depraved appetite is seen when cattle consume nonfeed materials such as dirt, sand, fine stone, and many other substances for no apparent reason. Many suggest that these habits can be explained on the basis of nutrient deficiency, but this has not been confirmed by research. One possible explanation for this habit is that such cattle are bored ${ }^{[2]}$. Cattle were developed anorexia due to infectious causes like bacteria and virus. For anorexia in viral and bacterial infection of domestic animals, including the bacterial species Salmonella, E. coli, Streptococcus, staphylococcus, and Corynobaecterium may be able to salt ${ }^{[6]}$. In the present study different age group were clinically showed anorexia that is (0-1) year 43\%, (01-03) year $41 \%$, above 3 year $16 \%$ (Table 1). The highest anorexia developed in 0-1 year age group and lowest found in above 3 years age group. Eating disorders affect people of all ages, especially early age in females, for whom it is the third most common chronic illness ${ }^{[13]}$. From this study it revealed that female cattle mostly developed anorexia. Research shows that more females were reported to have eating disorders than males, who make up only 5$10 \%$ of the population with eating disorders ${ }^{[8]}$. Age can affect the occurrence of parasitic infestation of animals ${ }^{[15]}$.

\section{CONCLUSION}

Anorexia is a global problem and considered as a major obstacle in the productive and reproductive performance of cattle. From this study it may be concluded that anorexia may develop by different causes. Host sex and age were highly relative with the occurrence of developing of anorexia. Female cattle were highly affected than that of male. The 0-1 year age group cattle were affected by diseases and developed anorexia than that of other age group.

\section{REFERENCES}

1. Afazuddin M (1985). General incidence and therapeutic measures of parasitic diseases in cattle of savar Military Farm. M.Sc. Thesis, Dept. of Medicine BAU, Myrnensingh.

2. Adams CR. (1982). Folic acid, thiamin and pyridoxine. In "Vitamins-The Life Essentials." National Feed Ingredient Association (NFIA), Des Moines, Iowa.
3. Alam MGS and Ghosh A (1991). Reproductive patterns of buffaloes in Bangladesh. Bang Vet J. 8: 39-43.

4. Balamurugan V, Saravanan P, Sen A, Rajak KK, Singh RK (2012). Prevalence of peste des petits ruminants among sheep and goats in India. J Vet Sci. 13(3): 279-285.

5. BGD MSN Weather (2009). Monthly Averages for Sylhet.

6. Blood (1979). Advance parasitology volume (24). Pp. 224.

7. Becker AE, Grinspoon SK, Klibanski A, Herzog DB (1999). Eating disorders. N Engl J Med. 340(14), 1092-1098.

8. Carlat DJ, Camargo CA, Herzog DB (1997). Eating disorders in males: a report on 135 patients. Am J Psychiatry 154(8):1127-1132.

9. Cockrill WR (1994). Present and future of buffalo production in the world. Proceedings of the Fifth World Buffalo Congress, 27-30 June, Sao Paulo, Brazil.

10. FAO (2001). Production year book.

11. Jones TC, Hunt RD, Kimg NW (1996). Veterinary Pathology. Williams \& Wilkins, A Waverly Company. Sixth Edition.

12. Khan CM (2000). The Merck Veterinary Manual. Merck Sharp \& Dohme Corporation. USA. 10th Edition.

13. Kreipe R.E, Birndorf SA (2000). Eating disorders in adolescents and young adults. Med Clin North A. 84(4): 1027-1049, viii- ix.

14. Latif MA (1994). Bufffalo production in Bangladesh problems and prospects. Proceeding of 1st Asian Buffalo Association Congress, January 17-21, Khon Kaen, Thailand.

15. Nuruzzaman $\mathbf{M}$, Haque $\mathbf{M H}$, Sarker $\mathrm{S}$ and Begum N (2012). Abomasal nematodes in Goats Slaughtered at Different Abattoir of Thakurgaon District, Bangladesh. J Sci Res. 4 (2): 491-497.

16. Patel MD, Nauriyal DS, Hasnani JJ and Gupta RS (2001). Prevalence of gastrointestinal parasitism in goats maintained under semiintensive and field management systems. Ind $J$ Vet Med. 21: 99-101.

17. Shahiduzzaman M, Alim MA, Rahman M and Mondal MMH (2003). Seasonal influence on the occurrence of Haemonchus contortus in slaughtered black Bengal goats in Bangladesh. Ban J Vet Med. 1: 45-48.

18. Schebendach J, Reichert-Anderson P (2000). Nutrition in eating disorders. In L. K. Mahan \& S. Escott-Stump (Eds.), Krause's food, nutrition, and diet therapy (10th., pp. 516533). Philadelphia: W.B. Saunders Company. 